\title{
A Bibliometric Analysis of Academic Publications About Intoxication in the Period From 1975 to 2020: A Global and Medical View
}

\author{
1975-2020 Yilları Arasında Zehirlenme Üzerine Akademik Yayınların Bibliyometrik Analizi: Küresel ve
} Tibbi Bir Bakış

${ }^{1}$ Musa Zengin, ${ }^{2}$ Onur Karaca

${ }^{1}$ University of Health Sciences, Ankara Atatürk Chest Diseases and Thoracic Surgery Training and Research Hospital, Anesthesiology and Reanimation Clinic Ankara,Turkey

${ }^{2}$ Aksaray University, Anesthesiology and Reanimation Clinic, Aksaray,Turkey

Correspondence:

Musa ZENGIN

University of Health Sciences,

Ankara Atatürk Chest Diseases and

Thoracic Surgery Training and

Research Hospital,

Anesthesiology and Reanimation

Clinic, Ankara, Turkey

e-mail: musazengin@gmail.com

\section{Abstract}

Intoxication is still the major cause of morbidity and mortality worldwide. Despite the growing number of global studies about intoxication, comprehensive bibliometric studies are not available in the literature. This study aims to analyze scientific articles about intoxication/poisoning and to evaluate this subject matter from a holistic point of view. Studies about intoxication that were published in the years between 1975 and 2020 were downloaded from the Web of Science (WoS) database and analyzed by bibliometric methods. Spearman's correlation coefficient was used for correlation analyses. Regression analysis was used to estimate publication trends in the coming years. A total of 32,320 publications about medical research were obtained. Of these publications, 17,508 (54\%) were articles. A non-linear growth trend was observed for the number of intoxication articles that have been published in recent years. The most active three institutions were the University of California San Francisco (137), Harvard University (133), and Oxford University (96). Clinical Toxicology was the journal that has published the highest number of articles (683). The most active author was Michael Eddleston (92). The most common subject matters were carbon monoxide, suicide, overdose, organophosphates, toxicology, alcohol, pesticides, epidemiology, children, paraquat, and lead poisoning. In this comprehensive bibliometric study about intoxication, which is a subject matter studied with a growing trend in the literature, we have presented a summary of 17,508 articles. This study can be a beneficial resource for clinicians and scientists by presenting global outputs about intoxication and future prospects and novel subject matters for research

Keywords: Bibliometric analysis; citation analysis; intoxication; poisoning; trend topics

\section{Özet}

İntoksikasyon tüm dünyada morbidite ve mortalitenin önemli bir nedeni olmaya devam etmektedir. Her geçen gün global araștırma sayısı artan intoksikasyon konusunda literatürde halen kapsamlı bir bibliyometrik çalışma bulunmamaktadır. Bu çalışmada intoksikasyon/poisoning konusunda yayınlanan bilimsel makaleleri analiz ederek konunun bütünsel olarak değerlendirilmesi amaçlanmıștır. İntoksikasyon konusunda 1975-2020 yılları arasında yayınlanmıș çalıșmalar Web of Science (WoS) veritabanından indirilerek istatistiksel ve bibliyometrik yöntemler kullanılarak analiz edildi. Korelasyon araştırmaları için Spearman korelasyon katsayısı kullanıldı. Gelecek yıllardaki yayın trendini tahmin etmek için regresyon analizi kullanıldı. Tıp araştırma alanlarında yayınlanan toplam 32320 yayın elde edildi. Bu yayınların 17508 (54\%)'i article idi. Intoxication konusunda üretilen makalelerin son yıllarda doğrusal olmayan bir trend ile arttığı görüldü. Literatüre en fazla katkı yapan ilk 5 ülke United States (4285), France (1221), United Kingdom (1350), Germany (1247), ve Japan (800) idi. En aktif ilk 3 kurum University of California San Francisco (137), Harvard University (133), ve University Oxford (96) idi. En fazla makale yayınlayan dergi Clinical Toxicology (683) idi. En aktif yazar Michael Eddleston (92) idi. En fazla çalışılan konular carbon monoxide, suicide, overdose, organophosphate, toxicology, alcohol, pesticide, epidemiology, children, paraquat ve lead poisoning idi. Literatürde her geçen gün makale sayısında artıs trendi olan intoxication konusunda yaptığımız bu kapsamlı bibliyometrik çalışmada 17508 makalenin bir özet bilgisi sunuldu. Bu makale intoxication konusundaki global çıktıları, araştırmaların gelecekteki ilerlemesi ve yeni araştırma fikirleri hakkında klinisyenler ve bilim adamlarına faydalı bir kaynak olabilir.

Anahtar Kelimeler: İntoksikasyon; zehirlenme; bibliyometrik analiz; alıntı analizi; trend topik 


\section{Introduction}

Damage caused by toxic substances that disrupt the vital functions of organisms upon their entry into the body is called intoxication. Intoxication or poisoning occurs when a hazardous substance that may cause illness or death (poison) is ingested, breathed, or touched by a person or when injected into a person (1). Common causes of intoxication include drugs, foods, fungi, corrosive substances, carbon monoxide (CO), insecticides, animal stings, alcohol (methanol and ethanol), gases, vapors, narcotics (heroin, etc.), stimulants (amphetamine, etc.), and volatiles (thinner, etc.) (2). Intoxication is the leading cause of unintentional injury-related deaths, emergency room visits, and hospitalizations (3). When treatment protocols per intoxication type are well implemented in emergency departments, relevant clinics, and intensive care units; mortality rates are reduced through timely and necessary interventions (4).

According to the 2019 Annual Report (37th Annual Report) of the American Association of Poison Control Centers (AAPCC; http://www.aapcc.org) based on the National Poison Data System (NPDS) receiving input from 55 poison control centers, human exposure cases leading to intoxication increased by $2.30 \%$ in 2019 compared to the figure in 2018 in the USA. The report noted that human exposures with less serious consequences have decreased by $2.08 \%$ per year since 2008 , while exposures with more serious consequences (major or fatal) have increased by $4.61 \%$ per year since 2000 . It has been reported that the first five classes of substances most frequently involved in all human exposures in 2019 were analgesics $(11.0 \%)$, household cleaning substances $(7.13 \%)$, cosmetics/personal care products (6.16\%), antidepressants (5.32\%), and sedatives/hypnotics/antipsychotics (5.21\%). Over the past 10 years, antidepressant exposures constituted the category showing the fastest increase with 1,957 cases with more severe consequences per year $(3.90 \%$ per year). The five most common exposures in 5-year-old and younger children were cosmetics/personal care products $(11.4 \%)$, household cleaning substances (10.5\%), analgesics $\quad(8.97 \%), \quad$ foreign bodies/toys/miscellaneous $\quad(7.17 \%), \quad$ and dietary supplements/herbals/homeopathics $(5.06 \%)(5)$.

Bibliometric analyzes are methods used to statistically analyze scientific publications, primarily articles (6-7). In parallel with the increasing number of publications in medicine in the literature, studies based on bibliometric analyzes have been conducted on many important subject matters in recent years (611). Bibliometric analyzes help to find out the most researched trending topics, the most cited impactful studies on a topic, and the most active authors, institutions, journals, and countries. Furthermore, international collaborations between authors, institutions, journals, and countries can be revealed by bibliometric analyzes (8-11). Bibliometric studies not only provide summary information about thousands of studies on a subject matter in the literature but also provide researchers with new ideas to study through a comprehensive list of past topics and current trends $(10,11)$.

Poisoning has been one of the major health problems throughout history. Intoxication is an important global public health problem with unintentional and deliberate exposures continuing to be a major cause of morbidity and mortality worldwide (12). Despite the increasing number of global studies, comprehensive bibliometric studies about intoxication are not available in the literature today. In this study, it is aimed to summarize and interpret the subject matter of intoxication holistically by analyzing scientific articles about intoxication/poisoning published in the years between 1975 and 2020 by using statistical and bibliometric methods. This way, it was aimed to reveal trending subject matters, to identify the most influential studies, countries, journals, and institutions, and to find out collaborations between countries. 


\section{Material and Methods}

\section{Search Strategy}

The Web of Science (WoS) database by Clarivate Analytics was used to perform the literature search. "Poisoning" and "intoxication" were the keywords for the literature search on WoS. The search was performed only in the "title" section of studies. Through this searching strategy, we obtained all publications that contained the words "poisoning" and "intoxication" in the title and that were published in the period between the years 1975 and 2020. All of the obtained publications were downloaded from the WoS database (access date: 01 March 2021). In order to allow researchers to obtain similar publications, the repeatability codes used in this study are offered as follows (search findings can be different on different access dates): "You searched for: title: (poisoning) or title: (intoxication) Timespan: 1975-2020. Indexes: SCI-Expanded, SSCI, $A \& H C I, C P C I-S, C P C I-S S H, B K C I-S, B K C I-$ $S S H, E S C I$." Studies that were indexed in research fields not relevant to medicine (Ecology, Substance abuse, Environmental sciences, Zoology, Electrochemistry, Energy Fuels, Plant sciences, Law, Economics, Fisheries, and Agronomy et al.) were excluded from this study.

\section{Statistical Methods}

VOSviewer (Version 1.6.15, Leiden University's Center for Science and Technology Studies) package software was used for bibliometric analyzes and network visualizations (13). The website, https://app.datawrapper.de, was used for drawing the world map. Statistical analyzes were performed using the SPSS (Version 22.0, SPSS Inc., Chicago, IL, USA) package software. The normality of the data distribution was tested with the Shapiro-Wilk test. In order to determine the factors affecting the productivity about publishing academic publications about intoxication, worldwide data were obtained from the World Bank about the number of articles and about some economic development indicators of countries including the Gross Domestic Product (GDP), the Gross Domestic Product per capita (GDP per capita), and the Human Development Index (HDI) (14). Correlations were tested by Spearman's correlation coefficient according to the distribution pattern of the data. Linear and non-linear regression analyses were used to estimate the number of publications in the coming years. The $\mathrm{R}^{2}$-value was used to compare the success of regression models. A p-value of $<0.05$ was accepted as the limit of statistical significance.

\section{Results}

\section{General Features of the Literature}

The literature search revealed a total of 46,592 publications about intoxication published in the WoS database in the period between the years 1975 and 2020. After excluding publications in research fields irrelevant to medicine, a total of 32,320 publications remained. Of these publications; 17,508 $(54.17 \%)$ were articles, $6,944(21.48 \%)$ were scientific meeting abstracts, 3,674 (11.37\%) were letters, $1,169(3.6 \%)$ were reviews, and $791(2.4 \%)$ were proceedings papers. The remaining ones were categorized as others with the following types of publications including editorial materials, notes, book reviews, book chapters, corrections, news items, early access articles, reprints, discussions, corrections-additions, books, bibliographies, and biographical items. Bibliometric analyses were conducted on 17,508 articles out of a total of 32,320 publications.

Of these articles, $86.1 \%(n=15,069)$ were in English. The remaining ones $(13.9 \%)$ were written in French (755), German (748), Russian (412), Spanish (277), Portuguese (70), Turkish (63), Italian (27), Polish (16), Japanese (11), Korean (9), Czech (8), Chinese (7), Ukrainian (6), Norwegian (5), Serbian (5), Slovenian (5), Afrikaans (3), Croatian (3), Dutch (2), Hungarian (2), Icelandic (2), Indonesian (2), and Lithuanian (1).

\section{Trajectory of Publishing Trends and Estimations for the Future}

The distribution of articles by year is shown in Figure 1. The linear and non-linear (quadratic model) regression analysis results used to 
estimate the number of articles in 2021 and beyond are shown in Figure 1.a and Figure 1.b. The quadratic model was the one that best fitted the model amongst all non-linear curves (quadratic: $\mathrm{R}^{2}=89.2 \%$ ). Furthermore, the fit of the quadratic model to the real data was better compared to the linear model (linear: $\mathrm{R}^{2}=47.3 \%$ ). Based on the results of the linear regression analysis, we estimated that 692 (CI\%: 602-782) articles would be published in 2021 and 729 (CI\%: 420-1038) articles would be published in 2025 (Figure 1.a). Based on the results of the nonlinear regression analysis, we estimated that 789 articles would be published in 2021 and 952 articles would be published in 2025 (Figure 1.b).

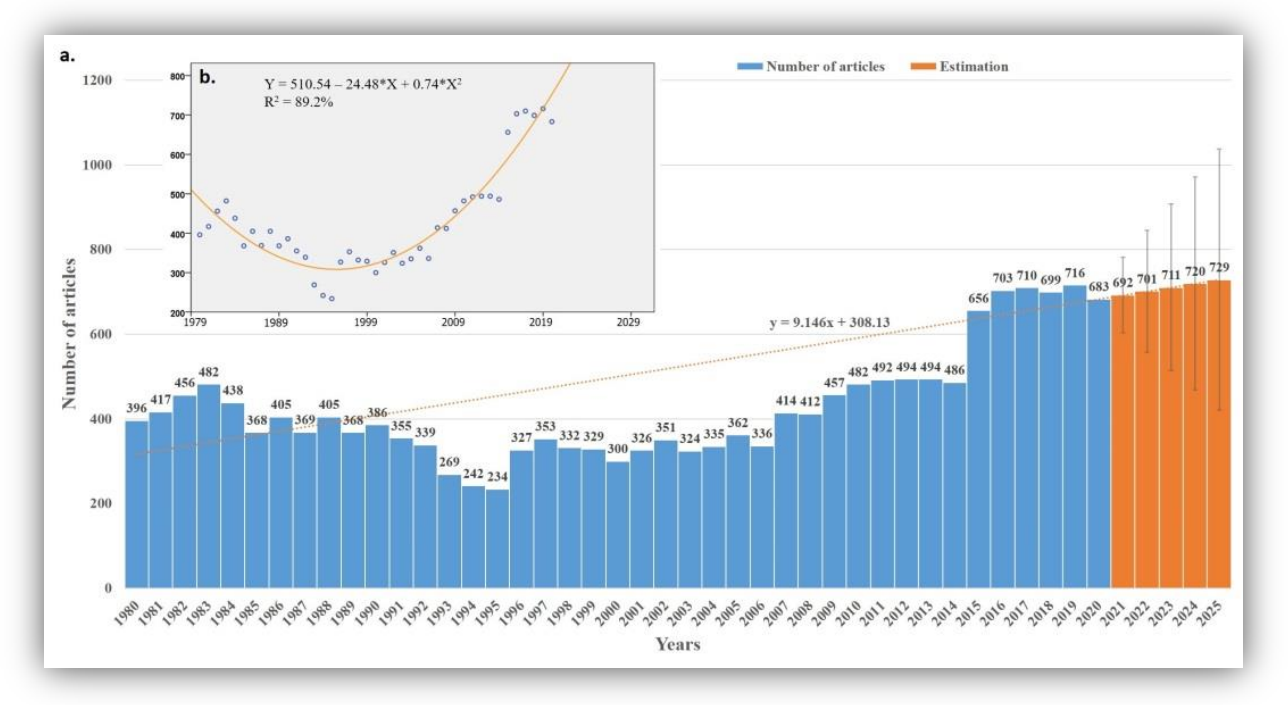

Figure 1. a. Linear regression model with the number of the published articles on intoxication by years and the estimation of the number of articles that can be published in the future b. Non-Linear regression model (quadratic curve)

\section{Research Areas}

The first 20 fields about intoxication research (fields, in which 200 or more articles were published) were Toxicology $(3605,20.6 \%)$, General Internal Medicine $(2872,16.4 \%)$, Pharmacology and Pharmacy (1981, 11.3\%), Public Environmental Occupational Health (1192, 6.81\%), Emergency Medicine (1135, 6.48\%), Pediatrics $(973,5.55 \%)$, Forensic Medicine (907, 5.18\%), Neuroscience (763, 4.35\%), Experimental Medical Research (691, 3.94\%), Clinical Neurology (690, 3.94\%), Biochemistry and Molecular Biology (665, $3.79 \%)$, Psychiatry $(647,3.69 \%)$, Pathology (446, 2.54\%), Critical Care Medicine (434, $2.47 \%$ ), Urology and Nephrology (312, $1.78 \%)$, Surgery (271, $1.548 \%)$, Anesthesiology (250, 1.42\%), Cardiac and Cardiovascular Systems (210, 1.19\%), Cell Biology (205, 1.17\%), and Infectious Diseases (202, 1.15\%).

\section{Active Authors}

The top 10 authors, who produced the highest number of articles about intoxication (more than 50 articles) were Eddleston $M(n=92)$, Buckley NA $(\mathrm{n}=82)$, Jacobsen D $(\mathrm{n}=59)$, Worek F $(n=59)$, Dawson AH $(n=56)$, Forrester MB $(\mathrm{n}=56)$, Garnier $\mathrm{R} \quad(\mathrm{n}=56)$, Kassa $J(n=55)$, Thiermann $\mathrm{H}(\mathrm{n}=53)$, and Hawton $\mathrm{K}(\mathrm{n}=51)$ respectively.

\section{Active Institutions}

The top most active 15 universities with the highest numbers of publications about intoxication (producing 80 or more articles) were the University of California San Francisco (137), Harvard University (133), University Oxford (96), University Colorado (95), the University of California San Diego (93), Hôpital Fernand-Widal (92), Shahid Beheshti University of Medical Sciences (90), University of Copenhagen (88), Newcastle University (88), University of Helsinki (86), University of Pittsburgh (86), University of 
Washington (84), University of Maryland (81), National Yang-Ming University (80), and University of Oslo (79).

\section{Active Journals}

A total of 17,508 articles about intoxication were published in 3,034 different journals. The first 55 most active journals that have published 40 or more articles, the number of articles published by the journals, the total number of citations received by the journals, and the average number of citations per article in the journals are presented in Table 1. The citation network visualization map presented in Figure 2 shows the increase in efficiency (in a spectrum from blue to red) based on the average number of citations per year received by respective journals, which are presented in Table 1.

Table 1. The top 55 most active journals that have published 40 or more articles on intoxication

\begin{tabular}{|c|c|c|c|c|c|c|c|}
\hline Journals & $\mathbf{R C}$ & $\mathbf{C}$ & $\mathrm{AC}$ & Journals & RC & $\mathbf{C}$ & $\mathbf{A C}$ \\
\hline Clinical Toxicology & 683 & 10481 & 15.3 & Intensive Care Medicine & 59 & 1282 & 21.7 \\
\hline $\begin{array}{l}\text { Journal of Toxicology-Clinical } \\
\text { Toxicology }\end{array}$ & 410 & 9024 & 22.0 & $\begin{array}{l}\text { Hong Kong Journal of Emergency } \\
\text { Medicine }\end{array}$ & 58 & 128 & 2.2 \\
\hline $\begin{array}{l}\text { Human \& Experimental } \\
\text { Toxicology }\end{array}$ & 401 & 6604 & 16.5 & Postgraduate Medical Journal & 57 & 796 & 14.0 \\
\hline Forensic Science International & 303 & 5409 & 17.9 & Archives de Pediatrie & 56 & 226 & 4.0 \\
\hline $\begin{array}{l}\text { American Journal of Emergency } \\
\text { Medicine }\end{array}$ & 234 & 6525 & 27.9 & $\begin{array}{l}\text { Schweizerische Medizinische } \\
\text { Wochenschrift }\end{array}$ & 56 & 375 & 6.7 \\
\hline Toxicon & 232 & 7908 & 34.1 & $\begin{array}{l}\text { Journal of Forensic and Legal } \\
\text { Medicine }\end{array}$ & 53 & 596 & 11.2 \\
\hline Journal of Forensic Sciences & 170 & 2333 & 13.7 & Lancet & 51 & 4445 & 87.2 \\
\hline Annals of Emergency Medicine & 168 & 5510 & 32.8 & South African Medical Journal & 50 & 635 & 12.7 \\
\hline $\begin{array}{l}\text { Bulletin of Experimental Biology } \\
\text { and Medicine }\end{array}$ & 142 & 119 & 0.8 & Southern Medical Journal & 49 & 726 & 14.8 \\
\hline Toxicology & 126 & 4571 & 36.3 & $\begin{array}{l}\text { Annales Francaises D Anesthesie et } \\
\text { de Reanimation }\end{array}$ & 48 & 282 & 5.9 \\
\hline Toxicology Letters & 124 & 2266 & 18.3 & Farmakologiya I Toksikologiya & 48 & 28 & 0.6 \\
\hline Archives of Toxicology & 117 & 2485 & 21.2 & Voprosy Meditsinskoi Khimii & 48 & 44 & 0.9 \\
\hline Journal of Emergency Medicine & 109 & 1254 & 11.5 & Toxicologie Analytique et Clinique & 47 & 61 & 1.3 \\
\hline Human Toxicology & 108 & 2321 & 21.5 & Clinical Pediatrics & 46 & 439 & 9.5 \\
\hline Pediatrics & 107 & 3390 & 31.7 & $\begin{array}{l}\text { American Journal of Industrial } \\
\text { Medicine }\end{array}$ & 45 & 1165 & 25.9 \\
\hline $\begin{array}{l}\text { Journal de Toxicologie Clinique } \\
\text { et Experimentale }\end{array}$ & 103 & 278 & 2.7 & European Journal of Pediatrics & 45 & 592 & 13.2 \\
\hline Pediatric Emergency Care & 103 & 985 & 9.6 & Chemico-Biological Interactions & 44 & 1180 & 26.8 \\
\hline Neurotoxicology & 100 & 2295 & 23.0 & Western Journal of Medicine & 44 & 933 & 21.2 \\
\hline $\begin{array}{l}\text { Deutsche Medizinische } \\
\text { Wochenschrift }\end{array}$ & 92 & 559 & 6.1 & Acta Clinica Belgica & 43 & 173 & 4.0 \\
\hline $\begin{array}{l}\text { Toxicology and Applied } \\
\text { Pharmacology }\end{array}$ & 92 & 2835 & 30.8 & Emergency Medicine Journal & 43 & 742 & 17.3 \\
\hline $\begin{array}{l}\text { American Journal of Forensic } \\
\text { Medicine and Pathology }\end{array}$ & 90 & 821 & 9.1 & Vrachebnoe Delo & 43 & 11 & 0.3 \\
\hline $\begin{array}{l}\text { Basic \& Clinical Pharmacology \& } \\
\text { Toxicology }\end{array}$ & 90 & 953 & 10.6 & Journal of Medical Toxicology & 42 & 250 & 6.0 \\
\hline British Medical Journal & 80 & 2384 & 29.8 & Medicina Clinica & 42 & 156 & 3.7 \\
\hline Medical Journal of Australia & 77 & 2001 & 26.0 & Presse Medicale & 42 & 385 & 9.2 \\
\hline $\begin{array}{l}\text { International Journal of Legal } \\
\text { Medicine }\end{array}$ & 73 & 894 & 12.2 & Journal of Biological Chemistry & 40 & 2192 & 54.8 \\
\hline Medicine & 68 & 392 & 5.8 & Psychopharmacology & 40 & 1022 & 25.6 \\
\hline Journal of Applied Toxicology & 66 & 880 & 13.3 & $\begin{array}{l}\text { Zeitschrift fur Rechtsmedizin- } \\
\text { Journal of Legal Medicine }\end{array}$ & 40 & 177 & 4.4 \\
\hline Critical Care Medicine & 62 & 1723 & 27.8 & & & & \\
\hline
\end{tabular}




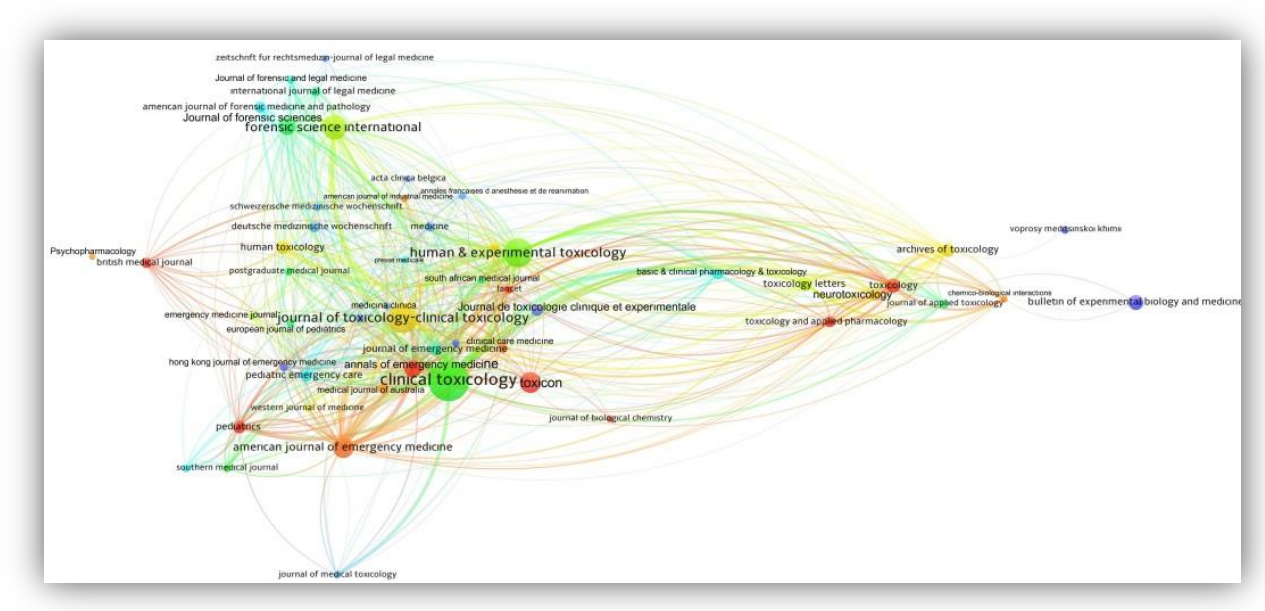

Figure 2. Network visualization map for the citation analysis of active journals that have published articles about intoxication. Footnote: A large circle shows that the number of articles is high (For example, Clinical Toxicology has the largest circle size, which indicates that the majority of the articles have been published in this journal). The number of citations increases as the color changes from blue to red (blue-green-yellow-red). For example, the following journals including Lancet, Journal of Biological Chemistry, Toxicology, Toxicon, Annals of Emergency Medicine, Paediatrics, Toxicology and Applied Pharmacology, British Medical Journal, American Journal of Emergency Medicine, and Critical Care Medicine are shown in red color because they received the majority of citations per article.

The indicator for the interpretation of colors is given at the bottom right.

Global productivity and performances of the countries

The distribution of the articles by country is shown in Figure 3. The top 20 most productive countries based on the number of articles were United States $(4,285)$, France $(1,221)$, United Kingdom $(1,350)$, Germany (1,247), Japan (800), Turkey (742), China (733), India (588), Australia (530), Canada (484), Italy (447), Spain (423), Taiwan (357), South Korea (347), Iran (307), Sweden (289), Brazil (285), Belgium (283), Switzerland (269), and Netherlands (246) respectively
(Figure 3). There were 170 countries that produced publications about intoxication. The international collaboration network visualization map of 65 countries, which included those countries that produced 20 articles and attended international collaborations, is presented in Figure 4. A statistically positive and highly significant correlation was found between the number of articles about intoxication per country and the following parameters including GDP, GDP per capita, and HDI of the respective country $(\mathrm{r}=0.763, \mathrm{p}<0.001 ; \mathrm{r}=0.707, \mathrm{p}<0.001, \mathrm{r}=0.703$, $\mathrm{p}<0.001$, respectively).

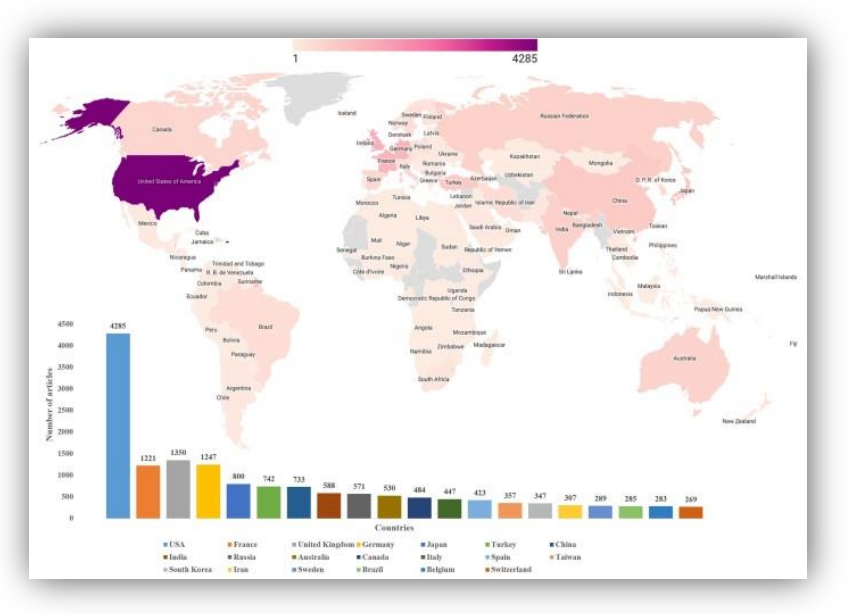


Figure 3. a. World map showing the distribution of articles about intoxication by the country. Footnote: The indicator is given at the top left. Darker colors indicate higher numbers of articles produced by respective countries. b. Top 20 countries publishing the highest number of articles.

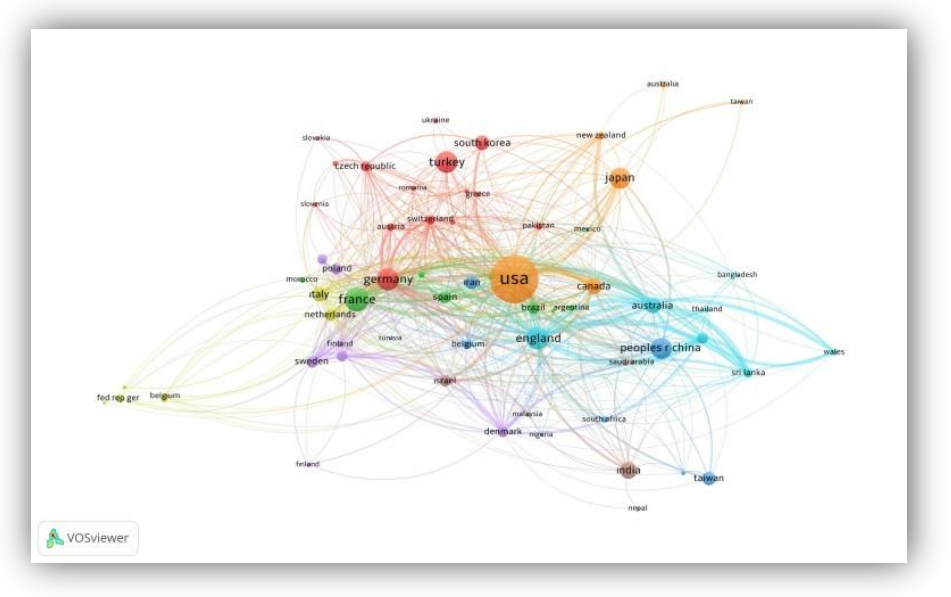

Figure 4. Network visualization map showing international collaborations about the subject matter of intoxication across countries. Footnote: The size of the circle is directly proportional to the increasing number of articles. The thickness of the lines indicates the strength of the relationship. The colors indicate different clusters. b. Density map showing international collaborations about the subject matter of intoxication. Footnote: Increasing international collaboration efforts are denoted by the changing color in the spectrum from blue to red (blue-green-yellow-red)

\section{Citation Analysis}

Among the 17,508 articles published during the 1975-2020 period, the first 20 articles with the highest number of citations are presented in Table 2. In the last column of Table 2, the average number of citations per article per year is presented.

Table 2. Top 20 most cited articles on intoxication according to total number of citations

\begin{tabular}{|c|c|c|c|c|c|c|}
\hline No & Article & Author & Journal & PY & TC & $\mathbf{A C}$ \\
\hline 1 & $\begin{array}{l}\text { Aquaporin-4 deletion in mice reduces brain } \\
\text { edema after acute water intoxication and } \\
\text { ischemic stroke }\end{array}$ & $\begin{array}{l}\text { Manley GT. et } \\
\text { al. }\end{array}$ & Nature Medicine & 2000 & 1089 & 49.5 \\
\hline 2 & $\begin{array}{l}\text { Mechanism of antitumor drug-action - } \\
\text { poisoning of mammalian DNA topoisomerase- } \\
\text { II on DNA by 4'-(9-acridinylamino)- } \\
\text { methanesulfon-meta-anisidide }\end{array}$ & $\begin{array}{l}\text { Nelson EM. et } \\
\text { al. }\end{array}$ & $\begin{array}{l}\text { Proceedings of the } \\
\text { National Academy of } \\
\text { Sciences of the United } \\
\text { States of America- } \\
\text { Biological Sciences }\end{array}$ & 1984 & 690 & 18.16 \\
\hline 3 & $\begin{array}{l}\text { Fatal microcystin intoxication in haemodialysis } \\
\text { unit in Caruaru, Brazil }\end{array}$ & Pouria S. et al. & Lancet & 1998 & 535 & 22.29 \\
\hline 4 & $\begin{array}{l}\text { Hyperbaric oxygen for acute carbon monoxide } \\
\text { poisoning }\end{array}$ & $\begin{array}{l}\text { Weaver LK. } \\
\text { et al. }\end{array}$ & $\begin{array}{l}\text { New England Journal } \\
\text { of Medicine }\end{array}$ & 2002 & 525 & 26.25 \\
\hline 5 & $\begin{array}{l}\text { Biomarkers of oxidative stress study II. Are } \\
\text { oxidation products of lipids, proteins, and } \\
\text { DNA markers of } \mathrm{CCl} 4 \text { poisoning? }\end{array}$ & $\begin{array}{l}\text { Kadiiska MB. } \\
\text { et al. }\end{array}$ & $\begin{array}{l}\text { Free Radical Biology } \\
\text { and Medicine }\end{array}$ & 2005 & 507 & 29.82 \\
\hline 6 & $\begin{array}{l}\text { Human intoxication by microcystins during } \\
\text { renal dialysis treatment in Caruaru-Brazil }\end{array}$ & $\begin{array}{l}\text { Azevedo } \\
\text { SMFO. et al. }\end{array}$ & Toxicology & 2002 & 483 & 24.15 \\
\hline 7 & $\begin{array}{l}\text { Poisoning severity score. Grading of acute } \\
\text { poisoning }\end{array}$ & $\begin{array}{l}\text { Persson HE. } \\
\text { et al. }\end{array}$ & $\begin{array}{l}\text { Journal of } \\
\text { Toxicology-Clinical } \\
\text { Toxicology }\end{array}$ & 1998 & 472 & 19.67 \\
\hline 8 & $\begin{array}{l}\text { Codeine intoxication associated with ultrarapid } \\
\text { CYP2D6 metabolism }\end{array}$ & $\begin{array}{l}\text { Gasche Y. et } \\
\text { al. }\end{array}$ & $\begin{array}{l}\text { New England Journal } \\
\text { of Medicine }\end{array}$ & 2004 & 430 & 23.89 \\
\hline 9 & $\begin{array}{l}\text { Involvement of nucleic-acid synthesis in cell } \\
\text { killing mechanisms of topoisomerase poisons }\end{array}$ & Darpa P. et al. & Cancer Research & 1990 & 426 & 13.31 \\
\hline 10 & $\begin{array}{l}\text { Aluminum poisoning - dialysis } \\
\text { encephalopathy, osteomalacia, and anemia }\end{array}$ & $\begin{array}{l}\text { Wills MR. et } \\
\text { al. }\end{array}$ & Lancet & 1983 & 425 & 10.9 \\
\hline 11 & Neurologic sequelae of domoic acid & Teitelbaum & New England Journal & 1990 & 409 & 12.78 \\
\hline
\end{tabular}




\begin{tabular}{|c|c|c|c|c|c|c|}
\hline & $\begin{array}{l}\text { intoxication due to the ingestion of } \\
\text { contaminated mussels }\end{array}$ & JS. et al. & of Medicine & & & \\
\hline 12 & $\begin{array}{l}\text { Choosing area based socioeconomic measures } \\
\text { to monitor social inequalities in low birth } \\
\text { weight and childhood lead poisoning: The } \\
\text { Public Health Disparities Geocoding Project } \\
\text { (US) }\end{array}$ & $\begin{array}{l}\text { Krieger N. et } \\
\text { al. }\end{array}$ & $\begin{array}{l}\text { Journal of } \\
\text { Epidemiology and } \\
\text { Community Health }\end{array}$ & 2003 & 403 & 21.21 \\
\hline 13 & $\begin{array}{l}\text { Carbon monoxide intoxication: An updated } \\
\text { review }\end{array}$ & $\begin{array}{l}\text { Prockop LD. } \\
\text { et al. }\end{array}$ & $\begin{array}{l}\text { Journal of the } \\
\text { Neurological Sciences }\end{array}$ & 2007 & 394 & 26.27 \\
\hline 14 & Carbon monoxide poisoning & Weaver LK. & $\begin{array}{l}\text { New England Journal } \\
\text { of Medicine }\end{array}$ & 2009 & 383 & 29.46 \\
\hline 15 & $\begin{array}{l}2004 \text { Annual report of the american association } \\
\text { of poison control centers toxic exposure } \\
\text { surveillance system }\end{array}$ & $\begin{array}{l}\text { Watson WA. } \\
\text { et al. }\end{array}$ & $\begin{array}{l}\text { American Journal of } \\
\text { Emergency Medicine }\end{array}$ & 2005 & 370 & 21.76 \\
\hline 16 & $\begin{array}{l}\text { Chronic central-nervous-system effects of } \\
\text { acute organophosphate pesticide intoxication }\end{array}$ & $\begin{array}{l}\text { Rosenstock L. } \\
\text { et al. }\end{array}$ & Lancet & 1991 & 355 & 11.45 \\
\hline 17 & $\begin{array}{l}\text { Delayed neurologic sequelae in carbon- } \\
\text { monoxide intoxication }\end{array}$ & Choi IS & $\begin{array}{l}\text { Archives of } \\
\text { Neurology }\end{array}$ & 1983 & 354 & 9.08 \\
\hline 18 & $\begin{array}{l}2003 \text { Annual report of the american association } \\
\text { of poison control centers toxic exposure } \\
\text { surveillance system }\end{array}$ & $\begin{array}{l}\text { Watson WA. } \\
\text { et al. }\end{array}$ & $\begin{array}{l}\text { American Journal of } \\
\text { Emergency Medicine }\end{array}$ & 2004 & 353 & 19.61 \\
\hline 19 & $\begin{array}{l}\text { Ethanol intoxication in Drosophila: Genetic } \\
\text { and pharmacological evidence for regulation } \\
\text { by the cAMP signaling pathway }\end{array}$ & $\begin{array}{l}\text { Moore MS. et } \\
\text { al. }\end{array}$ & Cell & 1998 & 350 & 14.58 \\
\hline 20 & $\begin{array}{l}\text { European Resuscitation Council Guidelines for } \\
\text { Resuscitation } 2010 \text { Section } 8 \text {. Cardiac arrest in } \\
\text { special circumstances Electrolyte } \\
\text { abnormalities, poisoning, drowning, accidental } \\
\text { hypothermia, hyperthermia, asthma, } \\
\text { anaphylaxis, cardiac surgery, trauma, } \\
\text { pregnancy, electrocution }\end{array}$ & Soar J. et al. & Resuscitation & 2010 & 349 & 29.08 \\
\hline
\end{tabular}

PY: Publication year, TC: Total citation, AC: Average citations per year

\section{Co-citation Analysis}

A total of 254,281 publications were cited in the references section of the 17,508 articles included in the analysis. Out of these articles, the top 7 studies that received the highest number of co-citations (more than 150 citations) were performed by Lowry (1951) [Number of co-citations (NC): 275], Persson (1998) (NC: 235), Ellman (1961) (NC: 223), Ernst (1998) (NC: 176), Weaver (2002) (NC: 171), Eddleston (2000) (NC: 163), and Weaver (2009) (NC: 154), respectively $(2,15-$ 20).

\section{Trend research topics}

In the 17,508 articles published on intoxication, 18,336 different keywords were used. Of these, 123 were the most commonly used keywords and they were used in at least 30 different articles. These keywords and the numbers of use are listed in Table 3. The cluster network visualization map of these keywords is shown in Figure 5. The trend visualization network map created to identify trend topics is shown in Figure 6.a and the citation network visualization map is shown in Figure 6.b.

Table 3. Top 123 most used keywords on intoxication

\begin{tabular}{llllllll}
\hline Keywords & NU & Keywords & NU & Keywords & NU & Keywords & NU \\
\hline $\begin{array}{l}\text { poisoning (s) } \\
\text { intoxication }\end{array}$ & 1676 & seizure (s) & 82 & hepatotoxicity & 47 & fatal intoxication & 35 \\
carbon monoxide & 255 & acetylcholinesterase & 81 & mercury & 46 & cholinesterase & 34 \\
$\begin{array}{l}\text { suicide } \\
\text { overdose }\end{array}$ & 254 & poison center & 79 & lipid peroxidation & 45 & GC-MS & 34 \\
$\begin{array}{l}\text { carbon monoxide } \\
\text { poisoning }\end{array}$ & 223 & soman & 76 & human & 44 & HI-6 & 34 \\
$\begin{array}{l}\text { organophosphate } \\
\text { (s) }\end{array}$ & 212 & forensic toxicology & 74 & pharmacokinetics & 44 & methanol & 34 \\
& & & & & intoxication & \\
\hline
\end{tabular}




\begin{tabular}{|c|c|c|c|c|c|c|c|}
\hline toxicology & 206 & $\begin{array}{l}\text { mushroom } \\
\text { poisoning }\end{array}$ & 72 & oximes & 43 & renal failure & 34 \\
\hline toxicity & 200 & treatment & 71 & aluminum phosphide & 42 & $\begin{array}{l}\text { emergency } \\
\text { medicine }\end{array}$ & 33 \\
\hline alcohol & 197 & adolescent (s) & 70 & brain & 42 & HPLC & 33 \\
\hline pesticide (s) & 186 & ethylene glycol & 69 & mice & 42 & $\begin{array}{l}\text { hyperbaric oxygen } \\
\text { therapy }\end{array}$ & 33 \\
\hline epidemiology & 178 & nerve agent (s) & 69 & $\begin{array}{l}\text { magnetic resonance } \\
\text { imaging }\end{array}$ & 41 & $\begin{array}{l}\text { organophosphorus } \\
\text { compounds }\end{array}$ & 33 \\
\hline rat (s) & 171 & self-poisoning & 69 & pregnancy & 41 & sarin & 33 \\
\hline children & 166 & outcome & 68 & acute kidney injury & 39 & urine & 33 \\
\hline paraquat & 160 & rhabdomyolysis & 67 & cadmium & 39 & benzodiazepines & 32 \\
\hline lead poisoning & 145 & food poisoning & 66 & drug abuse & 39 & blood & 32 \\
\hline mortality & 140 & hemoperfusion & 65 & methanol poisoning & 39 & $\begin{array}{l}\text { carbon monoxide } \\
\text { intoxication }\end{array}$ & 32 \\
\hline ethanol & 138 & opioid (s) & 62 & risk factors & 39 & Iran & 32 \\
\hline acute poisoning & 137 & paracetamol & 61 & arsenic & 38 & management & 32 \\
\hline forensic science & 136 & prognosis & 60 & drugs & 38 & childhood & 31 \\
\hline $\begin{array}{l}\text { poison control } \\
\text { center }(s)\end{array}$ & 123 & death & 57 & organophosphorus & 38 & diagnosis & 31 \\
\hline hemodialysis & 117 & liver & 57 & prevention & 38 & mitochondria & 31 \\
\hline antidote (s) & 113 & metabolic acidosis & 54 & carboxyhemoglobin & 37 & n-acetylcysteine & 31 \\
\hline oxidative stress & 110 & autopsy & 53 & lactate & 37 & surveillance & 31 \\
\hline $\begin{array}{l}\text { emergency } \\
\text { department }\end{array}$ & 99 & public health & 52 & pralidoxime & 37 & carbamate & 30 \\
\hline child & 97 & fatal poisoning & 50 & water intoxication & 37 & fomepizole & 30 \\
\hline lead & 97 & acute renal failure & 48 & forensic pathology & 36 & herbicide & 30 \\
\hline methanol & 92 & apoptosis & 48 & hyperbaric oxygen & 36 & infant & 30 \\
\hline $\begin{array}{l}\text { alcohol } \\
\text { intoxication }\end{array}$ & 91 & coma & 48 & LC-MS/MS & 36 & mass spectrometry & 30 \\
\hline $\begin{array}{l}\text { organophosphate } \\
\text { poisoning }\end{array}$ & 84 & lithium & 48 & paraquat poisoning & 36 & methadone & 30 \\
\hline atropine & 82 & poison & 48 & drug overdose & 35 & & \\
\hline
\end{tabular}

NU: Number of uses

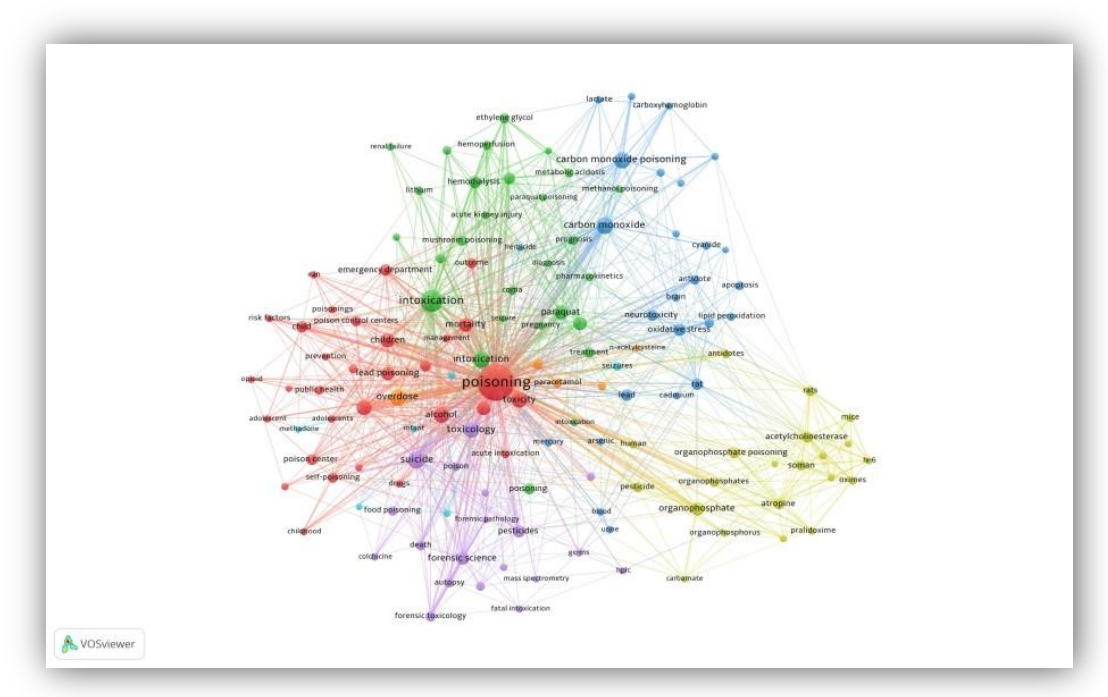

Figure 5. Network visualization map of the cluster analysis of the most commonly used keywords in intoxication research. Footnote: Colors show clustering. Keywords in the same cluster are shown in the same color. 


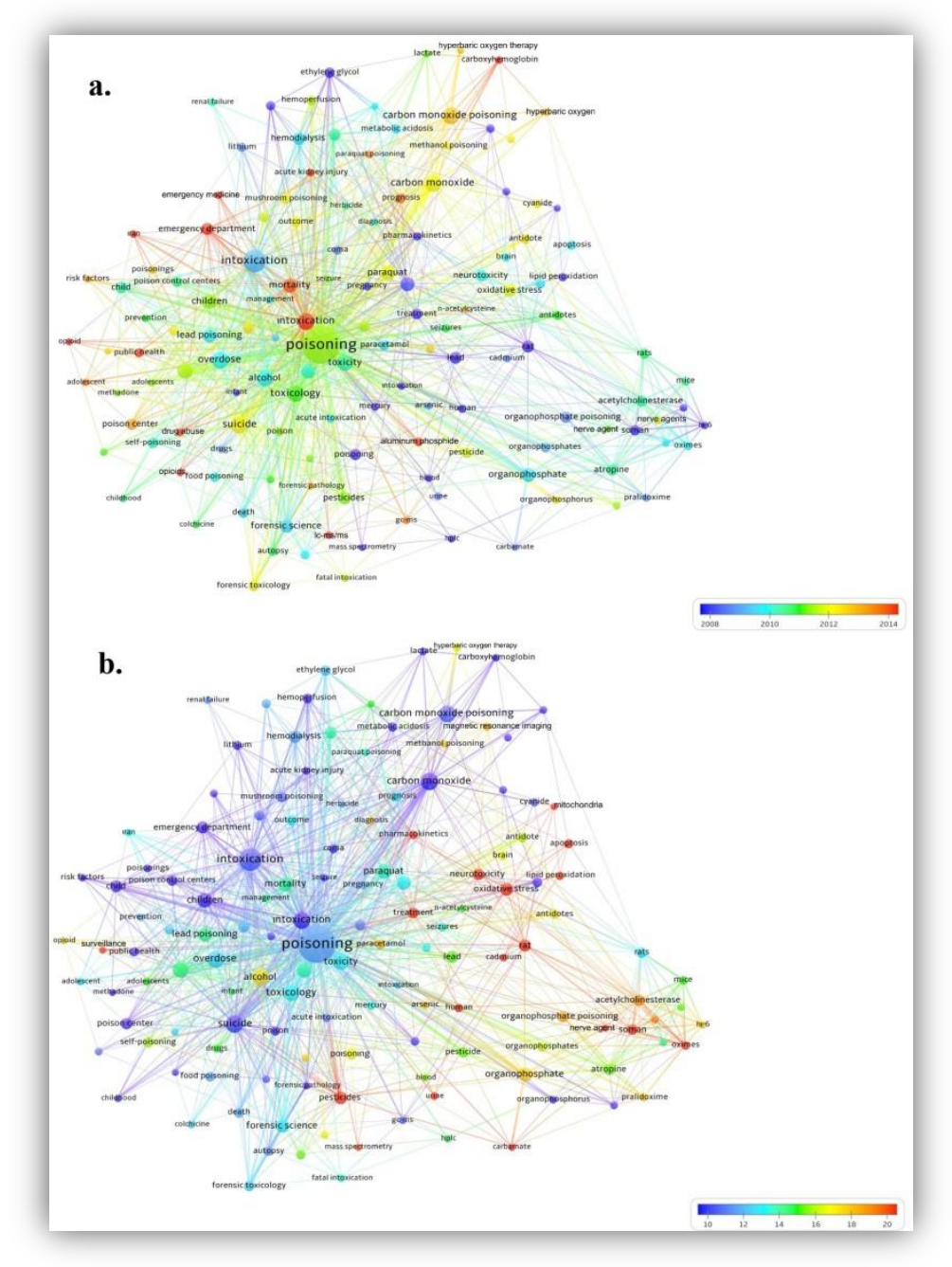

Figure 6. a. Trend network visualization map for the distribution of the most frequently used keywords in intoxication research by years. Footnote: Indicator shows current publications from blue to red (blue-green-yellowred). b. Network visualization map of the most frequently cited topics about intoxication Footnote: The number of citations increases in the spectrum from blue to red.

\section{Discussion}

Our study results have shown an increasing trend in the availability of articles about intoxication over the past years. Until the year 2014 so far (1980-2014), 381 articles were published on average. The number of articles has started to show a trend for a gradual increase since the year 2015 and reached an average of 695 articles per year in recent years (2015-2020). The highest number of published articles belongs to the year 2019 (716 articles). The results of the regression analysis lead to the suggestion that the increasing trend in the number of articles will continue.

The journals that published the highest numbers of articles about intoxication were
Clinical Toxicology, Journal of ToxicologyClinical Toxicology, Human \& Experimental Toxicology, Forensic Science International, American Journal of Emergency Medicine, Toxicon, Journal of Forensic Sciences, and Annals of Emergency Medicine in decreasing order of frequency. We may suggest that authors wishing to publish articles about intoxication should consider these journals in the first place. Based on the average number of citations per article, the citation analysis of the journals showed the most effective journals, which were listed as Lancet, Journal of Biological Chemistry, Toxicology, Toxicon, Annals of Emergency Medicine, Paediatrics, Toxicology and Applied Pharmacology, British Medical Journal, 
American Journal of Emergency Medicine, Critical Care Medicine, Chemico-Biological Interactions, Medical Journal of Australia, American Journal of Industrial Medicine, and Psychopharmacology in decreasing order of frequency (Figure 2). We can recommend that researchers wishing to have their articles to be cited more frequently should primarily consider submitting their manuscripts to these journals.

An examination of the distribution of published articles by countries showed that; of the most active 20 countries in publishing articles about intoxication, 15 were developed countries (United States, France, United Kingdom, Germany, Japan, Australia, Canada, Italy, Spain, Taiwan, South Korea, Sweden, Brazil, Belgium, and Switzerland) and 5 were developing countries (Turkey, China, India, Russia, and Iran). These developing countries were those with large economies. A bibliometric study on many different medical subjects in the literature demonstrated that developed countries or countries with great economic power were the ones that were most active in publication productivity. A high level of significant correlation was reported between the publication productivity and the economic power of the respective country $(7,9,11)$. Based on the correlation levels found between economic and developmental indicators and the article productivity in a specific country, we suggest that the economic scale of a country is the primary factor affecting the publication productivity about intoxication. The distribution of publications on the world map supports our findings (Figure 3).

It has been shown in the literature that geographical neighborhood plays a role in taking part in research through international cooperation $(9,10)$. When the international cooperation of countries is examined for coauthorship in publications about intoxication, it is observed that cooperation most commonly occurs among neighboring countries. However, cooperation among not neighboring countries is observed, too (Figure 4).

The examination of the articles based on the total number of citations revealed that the most cited study was the one conducted by
Manley et al., with the title "Aquaporin-4 deletion in mice reduces brain edema after acute water intoxication and ischemic stroke", which was published in 2000 in Nature Medicine (21). The second most impactful study was the one conducted by Nelson et al. (1984) and that study was published in Proceedings of the National Academy of Sciences of the United States of AmericaBiological Sciences, with the title "Mechanism of antitumor drug-action poisoning of mammalian DNA topoisomerase-II on DNA by 4'-(9acridinylamino)-methanesulfon-meta-

anisidide" (22). The third most commonly cited study was conducted by Pouria et al. (1998) and published in Lancet, with the title "Fatal microcystin intoxication in haemodialysis unit in Caruaru, Brazil" (23). The following most impactful studies were those conducted by Weaver et al. (2002) and Kadiiska et al. (2005) in the New England Journal of Medicine and Free Radical Biology and Medicine, respectively $(19,24)$. The examination of the studies based on the mean number of citations per year revealed that the most impactful article was the study reported by Manley et al. (2000) (21). The second, third, and the fifth most impactful articles were the $34^{\text {th }}, 32$ th, and $30^{\text {th }}$ Annual Reports of the American Association of Poison Control Centers' National Poison Data System (NPDS), which were published in Clinical Toxicology in years 2016, 2014, and 2012, respectively (25-27). The fourth most impactful study was the one, which was performed by Zhao et al. (2019), with the title "Chaos enhanced grey wolf optimization wrapped ELM for diagnosis of paraquatpoisoned patients" (28). The following most impactful studies were the ones performed by Kadiiska et al. (2005), Weaver (2009), and Rose et al. (2017) $(24,20,29)$. We suggest that clinicians interested in intoxication may prioritize reading the abovementioned studies.

When the keywords were analyzed by the cluster analysis, 5 main clusters were observed as visualized in 5 different colors (Figure 5). The cluster centers were the following subject matters including children/adolescents (alcohol, epidemiology, mortality, emergency department), forensic science (suicide, pesticides, autopsy), organophosphate, and carbon monoxide, 
paraquat/mushroom). The most commonly cited keywords were pesticides, oxidative stress, neurotoxicity, nerve agents, pharmacokinetics, soman, cadmium, oximes, carbamate, urine, mass spectrometry, rat, treatment, apoptosis, lipid peroxidation, mitochondria, and surveillance. The keyword analysis to find out trending subjects revealed that the following were the most commonly studies subject matters in recent years including opioids, lc-ms/ms, gc-ms, drug abuse, public health, mortality, Iran, emergency department/medicine, acute kidney injury, prognosis, carboxyhemoglobin, and aluminum phosphide. The analysis of the trending keywords revealed that emergency medicine and mortality were the most commonly studied subject matters in recent years. It was found out that liquid chromatography/double-mass

spectrophotometry (LCMS/MS) and gas chromatography/mass spectrophotometry (LCMS/MS) devices were used quite frequently over the past years. Drug abuse, acute kidney injury, and carboxyhemoglobin $(\mathrm{COHb})$, measured in $\mathrm{CO}$ intoxication cases at emergency department admissions, were the other most commonly studied subject matters. It is observed that the keyword, Iran, was used in articles commonly over the past years.

The literature review did not reveal any bibliometric studies about general intoxication. It can be argued that this comprehensive study, which we have performed, is the first bibliometric research in the literature. Zyoud et al. (2015, 2017, 2018) carried out bibliometric studies about calcium channel blocker poisoning, cocaine intoxication, and paraquat intoxication (3032). Sa'ed et al. $(2015,2016)$ performed bibliometric studies about methanol poisoning and paracetamol poisoning $(33,34)$. Our study covered all intoxication types including paracetamol (acetaminophen), glyphosate, mushroom, calcium channel blockers, cocaine, paraquat, methanol, and paracetamol. Considering the coverage and the number of articles included in the analysis, our study is the most comprehensive one amongst similar studies in the literature. The use of comprehensive statistical methods including cluster analyses, correlation analyses, regression analyses, and the keyword analysis to determine trends, as well as the use of descriptive statistics and citation analyses, contributed to the superiority of the present study.

A limitation of our study is that we used only the WoS database. We have not used the PubMed database in our study because PubMed does not allow citation and cocitation analyses. Furthermore, only journals with low impact factors and not indexed in the SCI-Expanded, SSCI, and E-SCI are listed in the Scopus database. Therefore, we did not use the Scopus database. Compared to other databases, the WoS database indexes the articles, which are published in journals with relatively higher impact factors $(35,36)$. Besides, the WoS database has been preferred more widely in bibliometric analyzes in recent years $(6-11,35,36)$. Finally, when more than one database is used in a bibliometric analysis study, the reliability is compromised because of the possibility that an article could be included in the study more than once.

\section{Conclusion}

In this comprehensive bibliometric study about intoxication, which is a subject matter showing an increasing trend in the number of relevant articles in the literature, we have shared a summary of 17,508 articles published in the years between 1975 and 2020. This article can be a useful resource for clinicians and scientists about global outputs and future advances in research about intoxication. According to World Health Organization data, $84 \%$ of deaths from unintentional poisoning worldwide in 2012 occurred in low- and middle-income countries. Our results show that the global research productivity was relatively low in low- and middle-income countries. Promotion of research about intoxication in such countries may be suggested to contribute to the build-up of epidemiological data about intoxication and to achieve a decline in the number of deaths due to intoxication in underdeveloped or developing countries. 


\section{REFERENCES}

1. Ahmed MB, Haile M, Tegene E. Prevalence and patterns of poisoning cases among patients presented to Jimma University specialized hospital: A five years retrospective data analysis. J Clin Toxicol, 2018:8; 2161-0495.

2. Eddleston M. Patterns and problems of deliberate self-poisoning in the developing world. QJM. 2000;93:715-31.

3. Lamireau T, Llanas B, Kennedy A, et al. Epidemiology of poisoning in children: a 7 year survey in a paediatric emergency care unit. Eur J Emerg Med. 2002;9:9-14.

4. Clinical management of acute pesticide intoxication: Prevention of suicidal behaviours. Geneva: World Health Organization; 2008.

5. Gummin DD, Mowry JB, Beuhler MC, et al 2019 Annual report of the American Association of Poison Control Centers National Poison Data System (NPDS): 37th Annual Report. Clin Toxicol (Phila). 2020 ;58:1360-1541.

6. Kiraz M, Demir E. A bibliometric analysis of publications on spinal cord injury during 1980-2018. World Neurosurg.2020;136:e504e513

7. Demir E, Yaşar E, Özkoçak V, et al. The evolution of the field of legal medicine: A holistic investigation of global outputs with bibliometric analysis. J Forensic Leg Med. 2020;69:101885.

8. Demir E, Comba A. The evolution of celiac disease publications: a holistic approach with bibliometric analysis. Ir J Med Sci. 2020 ;189:267-76.

9. Doğan G, Karaca O. Análise bibliométrica no campo da anestesiologia no período de 2009 . 2018 [A bibliometric analysis of the field of anesthesia during 2009-2018]. Braz J Anesthesiol. 2020;70:140-152.

10. Demir E, Akmeşe ÖF, Erbay $\mathrm{H}$, et al. Bibliometric analysis of publications on house dust mites during 1980-2018. Allergol Immunopathol (Madr). 2020;48:374-83.

11. Doğan $G$, İpek $H$. The Development of necrotizing enterocolitis publications: A holistic evolution of global literature with bibliometric analysis. Eur J Pediatr Surg. $2020 ; 30: 293-303$.

12. WHO https://www.who.int/ipcs/poisons/en/

13. van Eck NJ, Waltman L. Software survey: VOSviewer, a computer program for bibliometric mapping. Scientometrics. 2010 ;84:523-538.

14. The World Bank (2020). https://data.worldbank.org/indicator/NY.GDP. MKTP.CD [accessed 1 Mart 2021]

15. Lowry OH, Rosebrough NJ, Farr AL, et al. Protein measurement with the folin phenol reagent. J Biol Chem. 1951;193:265-75.

16. Persson HE, Sjöberg GK, Haines JA, et al. Poisoning severity score. Grading of acute poisoning. $J$ Toxicol Clin Toxicol. 1998;36:205-13

17. Ellman GL, Courtney KD, Andres V Jr, et al. A new and rapid colorimetric determination of acetylcholinesterase activity. Biochem Pharmacol. 1961;7:88-95

18. Ernst A, Zibrak JD. Carbon monoxide poisoning. $N$ Engl J Med. 1998:26;339:16038

19. Weaver LK, Hopkins RO, Chan KJ, et al. Hyperbaric oxygen for acute carbon monoxide poisoning. $N$ Engl J Med. 2002: 3;347:105767.

20. Weaver LK. Clinical practice. Carbon monoxide poisoning. $N$ Engl J Med. 2009: 19;360:1217-25.

21. Manley GT, Fujimura M, Ma T, et al. Aquaporin-4 deletion in mice reduces brain edema after acute water intoxication and ischemic stroke. Nat Med. 2000;6:159-63.

22. Nelson EM, Tewey KM, Liu LF. Mechanism of antitumor drug action: poisoning of mammalian DNA topoisomerase II on DNA by 4'-(9-acridinylamino)-methanesulfon-manisidide. Proc Natl Acad Sci USA. 1984 ;81:1361-5.

23. Pouria S, de Andrade A, Barbosa J, et al. Fatal microcystin intoxication in haemodialysis unit in Caruaru, Brazil. Lancet. 1998: 4;352:21-6.

24. Kadiiska MB, Gladen BC, Baird DD, et al. Biomarkers of oxidative stress study II: are oxidation products of lipids, proteins, and DNA markers of $\mathrm{CCl} 4$ poisoning? Free Radic Biol Med. 2005: 15;38:698-710.

25. Gummin DD, Mowry JB, Spyker DA, et al. 2016 annual report of the American Association of Poison Control Centers' National Poison Data System (NPDS): 34th annual report. Clin Toxicol (Phila). 2017 ;55:1072-1252

26. Mowry JB, Spyker DA, Brooks DE, et al. 2014 annual report of the American Association of Poison Control Centers' National Poison Data System (NPDS): 32nd annual report. Clin Toxicol (Phila). 2015;53:962-1147.

27. Mowry JB, Spyker DA, Cantilena LR Jr, et al. 2012 annual report of the American Association of Poison Control Centers' National Poison Data System (NPDS): 30th annual report. Clin Toxicol (Phila). 2013;51:949-1229.

28. Zhao X, Zhang X, Cai Z, et al. Chaos enhanced grey wolf optimization wrapped ELM for diagnosis of paraquat-poisoned patients. Comput Biol Chem. 2019;78:481490.

29. Rose JJ, Wang L, Xu Q, et al. Carbon monoxide poisoning: Pathogenesis, management, and future directions of therapy. Am J Respir Crit Care Med. 2017: 1;195:596606 
30. Zyoud SH, Al-Jabi SW, Sweileh WM, et al. Scientific research related to calcium channel blockers poisoning: Bibliometric analysis in Scopus, 1968-2012. Hum Exp Toxicol. 2015 ;34:1162-70.

31. Zyoud SH, Waring WS, Al-Jabi SW, et al. Global cocaine intoxication research trends during 1975-2015: a bibliometric analysis of Web of Science publications. Subst Abuse Treat Prev Policy. 2017: 2;12:6.

32. Zyoud SH. Investigating global trends in paraquat intoxication research from 1962 to 2015 using bibliometric analysis. Am J Ind Med. 2018;61:462-470.

33. Zyoud SH, Al-Jabi SW, Sweileh WM, et al. Bibliometric profile of the global scientific research on methanol poisoning (1902-2012). J Occup Med Toxicol. 2015: 3;10:17.

34. Zyoud SH, Waring WS, Al-Jabi SW, et al. The 100 most influential publications in paracetamol poisoning treatment: a bibliometric analysis of human studies. Springerplus. 2016:13;5:1534.

35. Golpinar M, Demir E. Global research output of the cerebellum: Yesterday, today, and tomorrow. J Anat Soc India 2020;69:155-65.

36. Doğan G, İpek $H$. The evolution of hypospadias publications: A bibliometric approach. Rev Int Androl. 2020:17:S1698031X(20)30023-6. 